\title{
Formation of ICT Competency of Bachelor Students While Studying the Course "Information Technologies" in Education
}

\author{
${ }^{1}$ Marina A. Lukoyanova, ${ }^{2}$ Nailya I. Batrova, ${ }^{3}$ Lyajlya L. Salekhova, ${ }^{4}$ Ramiz M. Aslanov \\ ${ }^{1-3}$ Kazan Federal University, Kazan, Tatarstan, Russia \\ ${ }^{4}$ Institute of Mathematics and Mechanics of the National Academy of Sciences of Azerbaijan, Baku, \\ Azerbaijan Republic \\ Email: marina-lkn@yandex.ru
}

Received: 23 ${ }^{\text {rd }}$ July 2019, Accepted: $10^{\text {th }}$ August 2019, Published: $31^{\text {st }}$ August 2019

\begin{abstract}
This paper presents the results of research work on the formation of information and communication technologies (ICT) competency of bachelor students in Teaching who studied the course "Information technology (IT) in education." In this regard, the concepts of "computer literacy", "ICT competence", "ICT competency" are clarified. Also the content and structure of ICT competence are clarified as the basis for the formation of student ICT competency; selection and structuring of the content of the course "Information Technologies in Education" are carried out; information and educational environment of the course are developed and tested. The main aim of the course is formation of ICT competency of students.

Monitoring of formation of ICT competency of students during 2018-2019 academic year was carried out on the results of the current and final control of students' progress on the course, input and final test of students for determining the level of formation of ICT competency. Also authors carried out the diagnostics of the orientation of students' motivation. Analysis of the level of students' ICT competency formation showed that it is formed mainly at the average and high levels. Also, it was noted an increase in the level of internal motivation of students after studying the course, due to the student's own activity, and its direct inclusion in the cognitive process.
\end{abstract}

\section{Keywords}

Computer Literacy, ICT Competence, ICT Competency, IT, Learning Motivation, Informational and Educational Environment.

\section{Introduction}

Modern age in the Russian Federation is characterized by ICT penetration into all spheres of public and professional life. Information is the most important resource for solving professional problems, and ICT is a means for the process of lifelong education, typical of a high-level professional, focused on the optimal solution of professional problems. In this regard, ICT competency is an integral part of a student's professional competency. The aim of its formation is one of the most important problem of higher education in training competitive specialists who own a universal tool for successful professional activity in any field.

ICT competency of a modern specialist includes the ability to work with computers, use ICT to solve professional problems, the ability to obtain the necessary information using network. In addition, a modern specialist must possess certain personal qualities, be capable of self-education in order to correspond to the level of development of information technologies. These requirements imposed by the Federal State Educational Standards (FSES) of Higher Education [1] to the level of preparation of the bachelor's degree students must also be implemented in the process of teaching courses connected with IT.

However, there is the problem of multi-level school preparation of students in the field of ICT. Therefore, it is necessary to build an optimal course for teaching students, aimed at the formation of their ICT competency, increase of learning motivation by means of ICT. These circumstances determine the need of selection of methods, forms and means of training that ensure effective work on the use of ICT in professional activities.

\section{Methods}

Features of Formation of ICT Competency of Bachelor Students

An analysis of scientific literature shows $[2,3]$ that the basis of the professionalism of the individual is competence. Competence is the ability and willingness to apply knowledge, skills, experience in solving professional problems in various fields. For example, according to the UNESCO ICT Competency Standards [4], modern teachers should work in an electronic information and educational environment, use ICT tools as additional and basic teaching materials for organizing students' individual and group work in conditions of electronic and blended learning; use ICT tools to increase the productivity of their labor; develop network materials, use the network as a tool for students to work in collaboration at school and beyond, etc.

Despite the widespread use of the concept of "information competency" it still has no clear and unambiguous definition in pedagogy. Clarification of the essence of this concept is based on the analysis of the words "competence", "competency" in psychological and pedagogical science. A common idea is that competency is as an alienated, predetermined social requirement for a student's educational background, which is necessary for his effective productive 
activity in a certain area. Competency is possession, mastering of a student of relevant competence, including his personal attitude to it and the subject of activity. Competency is the already existing quality of personality (set of qualities) of a student and minimal experience in a given field of activity.

According to competence-based approach the curriculum has to contain requirements and parameters that have to be achieved as a result of mastering the content. It follows that the main result of mastering course should be not just a system of knowledge, skills and experience, but a person's ability to successfully operate in a specific situation with the effective use of their totality, i.e. possession of competitiveness in modern society.

Information competency is considered both in the narrow and in the broad sense [5,6]. In a narrow sense, it is associated with the ability to use information technology, modern technical means and methods for searching, receiving, processing, presenting, transmitting information. In a broad sense - not only with the ability to use information technology to work with information, but also with the ability to carry out analytical and synthetic processing of information, to solve information retrieval tasks using the library as an information retrieval system, i.e. to carry out information activity using information technologies.

Thus, we consider that ICT competence of a bachelor student is understood as an emerging quality, while ICT competency is characterized as an achieved level of mastering certain competences [7].

According to A.V. Khutorskoy ICT competences are among the leading core competences. They imply a level categorization according to the amount of knowledge and skills developed in the field of modern information technologies, including the formation of personal attitudes and motivation to use ICT [8].

ICT competence of a bachelor student is a set of developing personal qualities (the ability search for and use the information received quickly, cognitive activity, emotional value attitude to information, communication skills), knowledge systems, skills, experience of information activities that characterize his ability professional activities using ICT [9].

In the structure of ICT competence of students, we have identified the following components [9]: value-motivational, cognitive, professional activity, communicative. A brief description of the components is presented in Table 1 .

\begin{tabular}{|l|l|}
\hline $\begin{array}{c}\text { Components of the ICT } \\
\text { competence }\end{array}$ & \\
\hline Value-motivational & $\begin{array}{l}\text { Student readiness for independent activities on mastering ICT; need for the development } \\
\text { of ICT competence; understanding of the importance of developing your own level of ICT } \\
\text { competence; emotional value attitude to information. }\end{array}$ \\
\hline Cognitive & $\begin{array}{l}\text { Knowledge and understanding of information and information processes, knowledge of } \\
\text { ICT and understanding of how to use them to solve educational and research problems }\end{array}$ \\
\hline Professional activity & $\begin{array}{l}\text { Ability to use information, possession of methods and search methods, etc .; application of } \\
\text { ICT in work with information in the process of professional activity. }\end{array}$ \\
\hline Ccommunicative & $\begin{array}{l}\text { The ability of flexible and constructive dialogue of various types, the idea of ethics and tact } \\
\text { of computer communication, etc. }\end{array}$ \\
\hline
\end{tabular}

Table 1: Characteristics of the Components of the ICT Competence of the Bachelor Student

Considering the multi-level school preparation of students in the field of ICT, three stages can be distinguished in the formation of ICT competency: computer literacy, ICT competence and the basics of ICT competency.

Computer literacy includes elementary computer skills: creating and editing of files; playing audio and video; using external drives; knowledge of working principles and connecting peripheral devices; understanding of the operating and file system.

Formation and development of ICT competencies of students is aimed at the formation and development of educational and general user ICT competency (the ability to cooperate and communicate, to acquire, replenish and integrate knowledge independently, the ability to solve personally and socially significant problems and practical problem solving using ICT).

The formation of ICT competencies can be distinguished into: creation and formatting of text documents of a complex structure automatically; introduction of objects between software (e.g. MS Office); information search in networks, information educational resources, electronic libraries; recording information, etc.; structuring knowledge, and presenting them in the form of diagrams, graphs, etc.; creation and using of multimedia products; saving and processing of images, sounds, etc.; using web 2.0 etc.

Such competencies are important in the structure of ICT competencies that allow to enable communication and interaction: knowledge of network etiquette; knowledge of the basics of Internet security; participation in the discussion (video-audio, text materials); sending and forwarding letters; Internet newsletter to the target audience; participation in the forum; interaction in social groups and networks, collaborative work on the document (sharing).

\section{Formation of ICT Competency of Bachelor Student}

ICT competency must be purposefully formed in the process of mastering students while studying various courses on IT. Therefore, the curriculum in Teaching of Institute of Philology and Intercultural Communication of KFU included the different courses on IT. Let us consider the formation of ICT competency on the example of the course "IT in education." The purpose of the studying of students of this course is to improve the skills and the formation of positive motivation 
for the use of ICT, the formation of the needs and skills to use ICT to increase the efficiency of their professional activities independently.

The curriculum includes four units that will allow to master fully the material of the subject: ICT in educational and research activities; preparation of test materials based on ICT; the use of Internet in the activities of the teacher; basics of information security.

The features of the learning process are following: 1) practical significance of the tasks performed, aimed at solving educational and research problems; 2) focus on developing practical skills in working with ICT and computers during independent work; 3) orientation on mutual assistance and consultations of the professor during practical tasks.

The informational and educational environment of the course provides the implementation of blended learning. It contains theoretical material, educational video, practical tasks, folders with completed tasks for professor verification, a progress report, questions for final testing and an online test.

For the formation of the value-motivational component of ICT competence, positive motivation of students to master ICT is necessary, which can be provided by:

1) highlighting the main objectives of training and the creation of conditions for the awareness of the objectives of student learning;

2) creation of conditions for students to realize the theoretical and practical significance of the acquired knowledge and experience;

3) orientation towards future professional activities and prospects for its development;

4) professional orientation in the educational process.

The cognitive component involves the system of knowledge on information and methods of its processing, ensuring productive activity in working with it; understanding of wide area networks, their role in modern society; general cultural knowledge of the modern information view of the world.

Professional activity components include the possession of the main methods, ways and means of obtaining, storing, processing various types of information; ability to work with information in wide area networks; ability to structure, analyze, compare, summarize information, etc.

The communicative component includes the ability and willingness to use various methods, forms and means of establishing communication, organizing communication in networks.

It was carried out the current control of progress on the basis of a grade-rating system in the process of studying the course by the students. It is a sum of grades for performing practical work.

The level of formation of ICT competence and basics of ICT competency according to the results of experimental activities is verified using the obtained results of current control and final online test, input and final test results, as well as an online survey on the study of the orientation of students' educational motivation [10].

\section{Results and Discussion}

The assessment of the level of the formation of ICT competence of 79 first year bachelor students ( 3 groups) was conducted during 2018-2019 academic year. The monitoring of the results of the current and final control of the progress of students was carried out on the basis of a grade-rating system and was calculated by average values of the maximum possible value (Fig. 1).

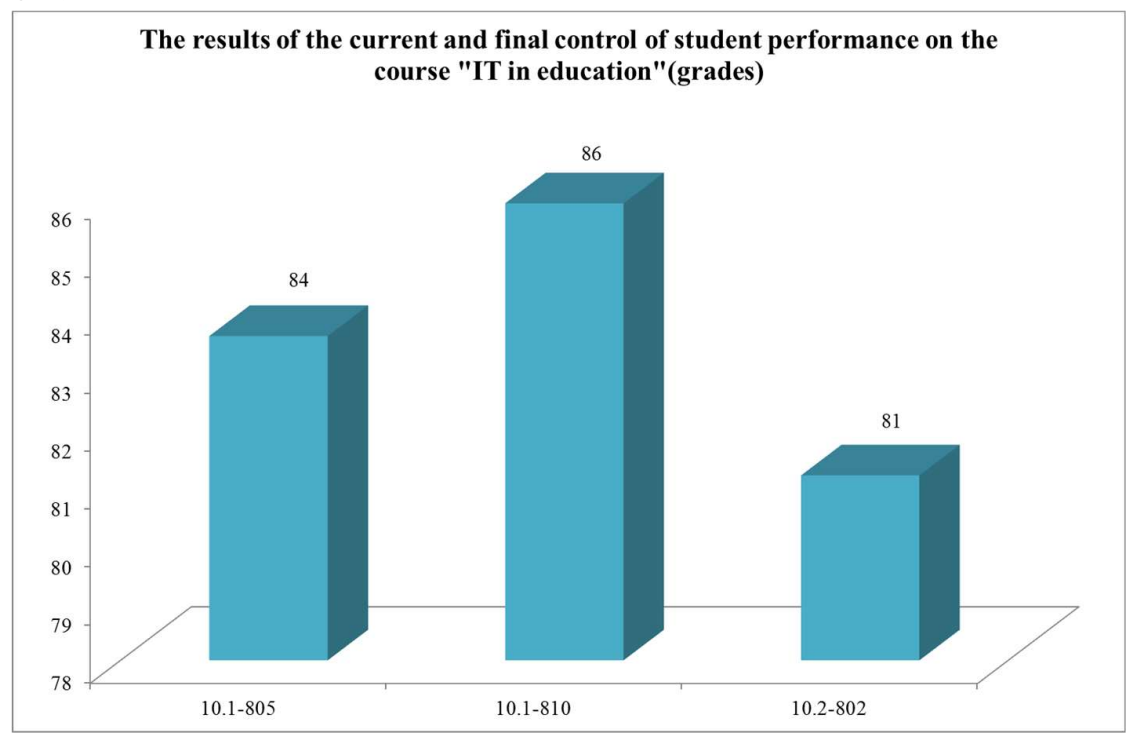

Fig. 1: Monitoring of the Results of the Current and Final Control of Student Performance

The authors identified three levels of formation of ICT competency using ICT (low, average and high) and analyzed the results of test before and after the completion of the course. The diagnostic results are presented at fig. 2 


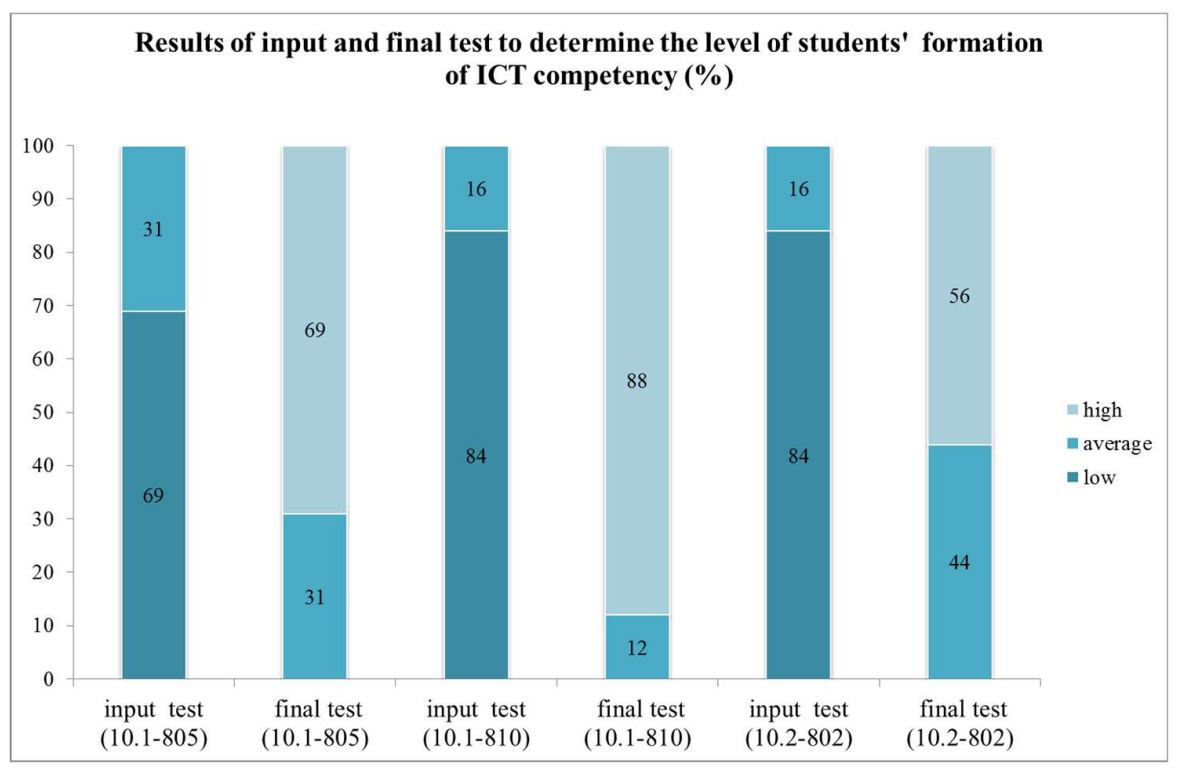

Fig. 2: Comparative Data of Input and Final Test to Determine the Level of Students' Formation of ICT Competency

Selection of intervals in determining the results of testing of students is carried out according to the method proposed by Kyveryalg A.A [11]:

- $\quad$ low till 25\% (computer literacy level);

- $\quad$ average from $26 \%$ till $75 \%$ (ICT competence level);

- $\quad$ high from $76 \%$ till $100 \%$ (the level of formation of ICT competency).

Irregular intervals is also explained by the fact that most often the experience of activity is formed on average level and less often on high one.

Monitoring of the orientation of learning motivation [10], which allows evaluate formation of the value-motivational component of students' ICT competence by means of ICT was conducted sample-based, just who wanted to take the survey. So 56 students took part in the survey. Before the start of training, internal motivation prevailed among 35 students, while 21 students had external motivation. After studying the course internal motivation (student's own activity, direct inclusion in the cognition process) was dominated in 46 students, and external motivation (getting good grades, scholarships, praise from parents, etc.) prevailed among 10 students (Fig. 3).

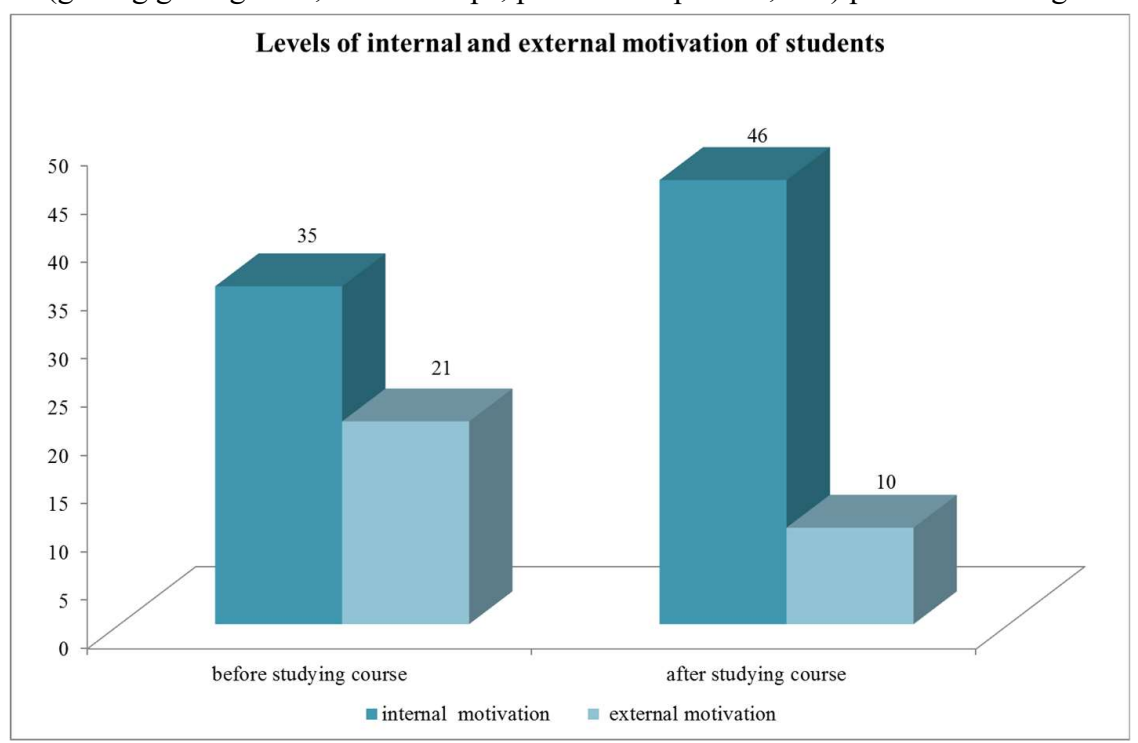

Fig. 3: Levels of Internal and External Motivation of Students

We analyzed the results of their training on the course on the basis of monitoring the results of the current and final performance assessed by the grade-rating system. As a result, group 10.1-805 showed an average grade of 84, group 10.1810 - 86 grades and group of 10.2-802 - 81 grades. 
Diagnostics of the levels of formation of students' ICT competency using ICT showed that before the beginning of the course, students basically had computer literacy and basic ICT competencies, after - students had formatted their ICT competency.

For the effective organization of ICT training of students, the increasing their learning motivation had a great importance. As the results of diagnostics of the orientation of students' motivation showed: before the beginning of the course, internal motivation prevailed among 35 students, 21 students had external motivation; after completing the course, internal motivation prevailed among 46 students, and 10 students had external motivation.

\section{Summary}

ICT competence of student is understood as an emerging quality, while ICT competency is characterized as the achieved level of mastering certain competencies.

As part of the study, the authors identified three stages in the formation of student's ICT competency: computer literacy, ICT competence, basics of ICT competency.

Besides the structure and content of ICT competence were defined. There are: value-motivational, cognitive, professional activity and communicative components.

The paper presents the results of an experiment conducted at the Institute of Philology and Intercultural Communication of KFU in order to identify the level of formation of students' ICT competency. Experimental work and mathematical processing of the results indicate the effectiveness of the developed information and educational environment of the course "IT in education" in the formation of ICT competency of bachelor students in Teaching.

\section{Conclusions}

In the conditions of an informational high-tech society the field of vocational education should be focused on training qualified specialists who are ready for life and professional activity, developing their personal qualities and skills, the professional competency demanded by the society. Nowadays one of its components is ICT competency. Therefore, ICT training is becoming urgent, aimed at developing ICT competency of students, which characterizes their readiness and ability for informational activities to solve professional problems using ICT.

\section{Acknowledgements}

The work is performed according to the Russian Government Program of Competitive Growth of Kazan Federal University.

\section{References}

[1] On approval of the federal state educational standard of higher education - bachelor's degree in the field of training 44.03.05 Pedagogical education. URL: http://fgosvo.ru/uploadfiles/FGOS\%20VO\%203++/Bak/440301 B 3 16032018.pdf (accessed on 22/01/2019)

[2] Abdrafikova A.R., Akhmadullina R.M., Yarmakeev I.E. "Formation of the communicative competence in students future pedagogues for working with gifted pupils”, Social Sciences (Pakistan), vol. 10, Issue 7, pp. 1817-1821, 2015.

[3] Yarmakeev I.E., Akhmadullina R.M., Valiakhmetova N.R., Salpykova I.M. "Potential of pedagogical disciplines for forming ethno-cultural competence of students - Future teachers", Astra Salvensis, vol. 6, 2018, pp. 275-285.

[4] UNESCO ICT Competency Framework for Teachers. URL: https://unesdoc.unesco.org/ark:/48223/pf0000265721

[5] L. Liukineviciene. Biblionova methodology for the development of academic community's information culture // EDULEARN09 Proceedings. - 2009. PP. 5228-5239.

[6] A. Danilov, L. Salekhova, T. Yakaeva. Developing computer literacy of bilingual students through CLIL // INTED2018 Proceedings. - 2018. PP. 1967-1971.

[7] Zimnyaya I.A. (2014). Competence and competence in education. Ejdos. № 4. pp. 18-28.

[8] Hutorskoj A.V., Trishina S.V. Information competence of a specialist in the system of additional professional education. Ejdos.URL: http://www.eidos.ru/journal/2004/0622-09.htm

[9] Lukoyanova M., Grigorieva K., Grigoriev S., Batrova N. (2017). The Usage of IT in forming Students' Information Competency. Revista Publicando, vol.4, № 13. (1), pp. 574-584.

[10] Dubovickaya T.D. (2002). The technique of diagnostics of educational motivation orientation. Psychological science and education. №2, pp. 42-45.

[11] Kyveryalg A.A. (1980). Research methods in professional pedagogy. Tallin: Valgus, 334 p. 